\title{
Genetic diversity and environmental associations of wild emmer wheat, in Turkey
}

\author{
E. Nevo, \\ A. Beiles and \\ D. Kaplan
}

Institute of Evolution, University of Haifa, Mount Carmel, Haifa 31999, Israel.

Genetic diversity within and between Turkish populations of the wild progenitor of wheats, tetraploid wild emmer wheat, Triticum turgidum var. dicoccoides, was studied electrophoretically. Forty-eight enzyme loci were assayed in 157 individual plants representing four populations of $T$. $t$. dicoccoides, across a transect of $90 \mathrm{~km}$ in Turkish Kurdistan. The following results were indicated: (i) $T$. $t$. dicoccoides in Turkey comprises medium levels of allozyme diversity. Out of 48 putative loci 19 (40 per cent) were polymorphic and the level of genetic diversity was medium $\mathrm{He}=0 \cdot 057$. (ii) Altogether we scored 72 alleles in the 48 loci. (iii) The population genetics structure of $T$. $t$. dicoccoides in Turkey, similar to that in Israel (Nevo et al., 1982), displayed an ecological-genetic, semi-isolated, "archipelego". Thirteen of the 24 variant alleles (or 54 per cent) were localized. (iv) The mean genetic distance between populations was $D=$ $0 \cdot 046$, range $0.019-0.082$. (v) About 86 per cent of the plants (101 out of 117) analyzed by discriminant analysis were correctly classified in their population spaces. (vi) Genetic diversity, $\mathrm{He}$, and some representative allele frequencies were significantly explained by two variable combinations of water, temperature or geographical factors. (vii) 63 per cent of the allozyme variation was within and 37 per cent was between populations. (viii) Significant gametic phase disequilibria abound, displaying allele association at the two-locus level. (ix) Strong allele associations occur at the multilocus level at the megapopulation and at each of the 4 populations. On the average, the megapopulation was 71 per cent higher in the number of expected heterozygous loci, $K$, than that expected under random associations; the range between populations was $X(2)=29-125$ per cent.

These results suggest that (i) climatic selection plays an important role in genetic differentiation of wild emmer populations, and (ii) the wild gene pool comprises significant genetic resources for utilization in wheat improvement.

\section{INTRODUCTION}

We have reported earlier on levels of genetic diversity at the macro- and microgeographic differentiation, and highlighted environmental correlations with allozyme diversity in wild emmer wheat, $T$. $t$. dicoccoides ( $T$. turgidum, in Kimber and Feldman, 1987) in Israel (Nevo et al., 1982; Nevo, 1983; Golenberg, 1986; Golenberg and Nevo, 1987; Nevo et al., $1988 a, b$ ). The present report complements the others in our attempt to trace genic differentiation of wild emmer in the Near East Fertile Crescent. The Fertile-Crescent belt is the centre of origin and diversity of wild emmer wheat, the progenitor of all cultivated wheats, as well as the centre of the other 27 species of the genus Triticum, (Kimber and Feldman, 1987). Clearly, the knowledge of geographic patterning of genic diversity across the centres of diversity of the progenitors of cultivated plants may be of great importance. This is true both theoretically, in assessing the evolutionary forces of genetic differentiation, and practically, in utilizing the genetic resources of the wild gene pool in breeding programmes for wheat improvement.

Modern plant breeding practices have reduced the genetic diversity in cultivated plants, including wheats, making them increasingly susceptible to diseases, pests, and environmental stresses (Plucknett et al., 1983). Consequently, the maintenance of high world food production is severely threatened. As often argued (e.g., Feldman and Sears, 1981) the highest hope for future crop improvement lies in exploiting the genetically diverse and adaptive gene pool of the plants' wild relatives. The wild gene pools of wheat contain many economically important alleles for disease resistance, high grain protein content, resistance against diverse ecological stresses, earliness, etc., that might be transferred to cultivated wheats and 
utilized in their improvement (Feldman, 1983; Nevo, 1983, 1987; Kimber and Feldman, 1987).

The objective of this paper is to document the genetic structure and differentiation of populations based on allozymes of wild emmer wheat, $T$. $t$. dicoccoides, in Turkey. This data base will be compared and contrasted in a later communication with Israeli populations of wild emmer. Here we demonstrate that the level of genetic diversity of wild emmer in Turkey is relatively medium. However, the unique "archipelago" genetic population structure of wild emmer wheat is clearly displayed, partly correlated with the climatic environment. The genetic resources described here in wild emmer wheat could be utilized in wheat improvement.

\section{MATERIALS AND METHODS}

\section{Ecological background}

Wild emmer wheat, $T$. $t$. dicoccoides ( $T$. turgidum in Kimber and Feldman, 1987; genomic constitution $A B$ ), is the tetraploid, predominantly self pollinated, wild progenitor from which modern tetraploid and hexaploid cultivated wheats were derived (Zohary, 1970; Feldman, 1976; Kimber and Feldman, 1987), and with which it makes fertile hybrids. Wild emmer is distributed over the Near East Fertile Crescent, in Israel, Jordan, Lebanon, Syria, East Turkey, North Iraq and West Iran (Harlan and Zohary, 1966; Kimber and Feldman, 1987). The centre of distribution of $T$. $t$. dicoccoides is found in the catchment area of the Upper Jordan Valley in Israel and vicinity. In Turkey, T. $t$. dicoccoides grows as an annual component in several steppe-like herbaceous formations in Turkish Kurdistan primarily on basalt soils. It ranges from warmer and drier (lower in altitude, around $650 \mathrm{~m}$, population No. 1, equivalent to population No. 7 of wild barley, see fig. 1 and Nevo et al., 1986) to cooler and wetter (higher in altitude, around $950 \mathrm{~m}$, population No. 2 , equivalent to population No. 8 of wild barley, fig. 1) environments (see detailed ecogeographical background in table 1). It is found in primary habitats around the open park forest of Quercus brantii, but is primarily abundant in secondary habitats near rocks and boulders of basalt. It grows with other wild cereals like wild barley, wild oats, and wild diploid wheats but has by far a more restricted, scarce, patchy and locally isolated pattern of distribution, as compared with the above

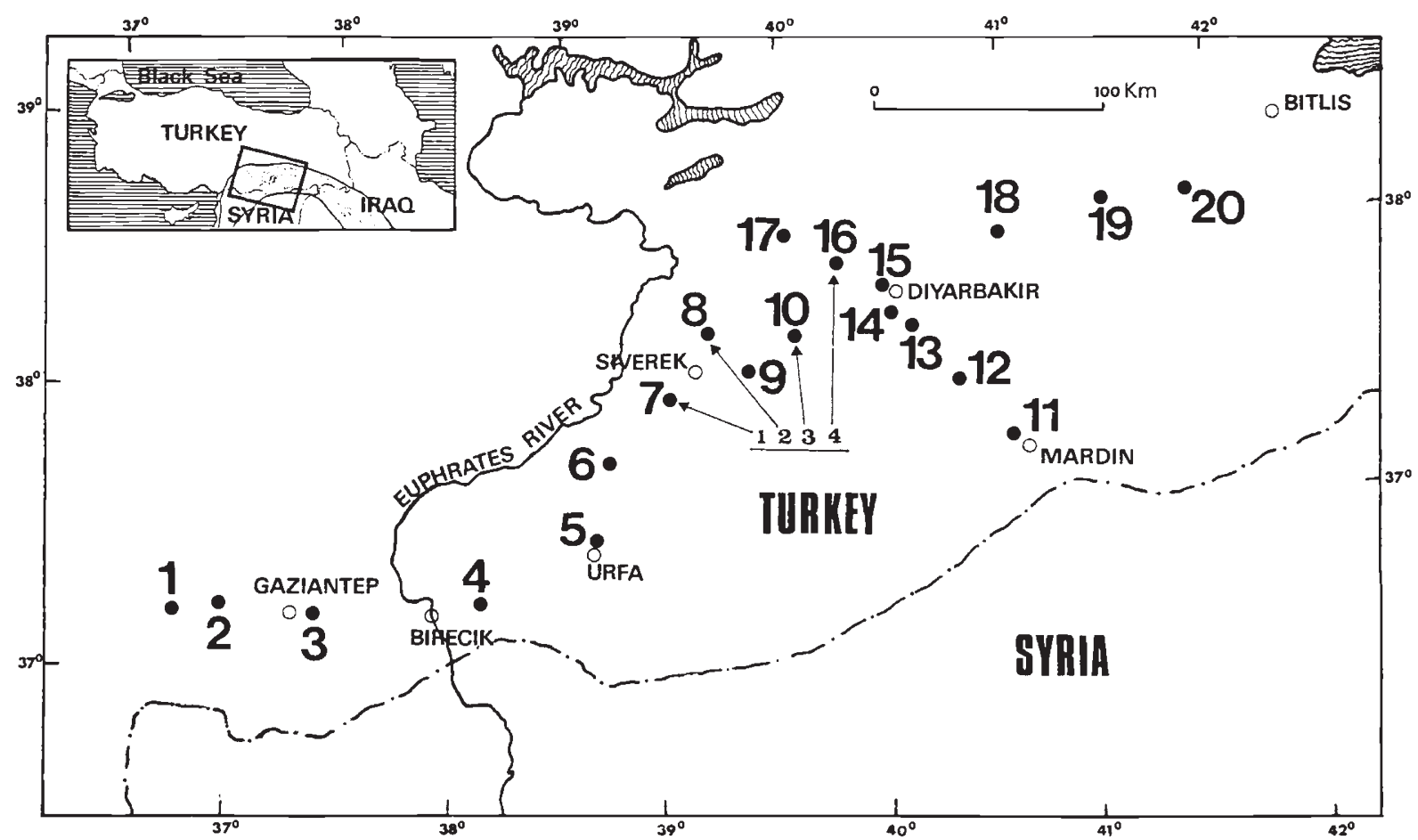

Figure 1 Geographic distribution of 20 sampling localities of wild cereals in Turkey. In only four localities 7, 8, 10 and 16, referred here as populations Nos. 1, 2, 3, 4 was wild emmer wheat, T. t. dicoccoides found. 


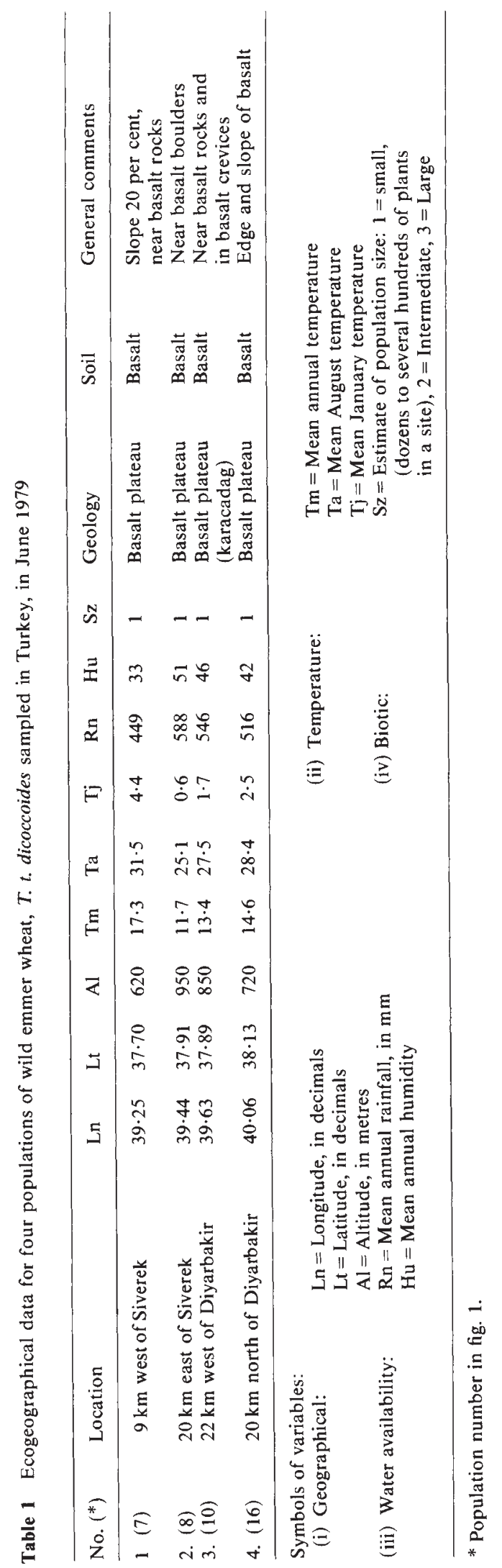


mentioned wild cereals. Populations comprised, at most, several hundreds of individual plants (see table 1). Climatic data are mainly from the Atlas of Turkey (1961); soil data are based on personal field observations of the senior author.

\section{Sampling}

A total of several hundred spikes representing four populations of wild emmer, $T$. $t$. dicoccoides, was collected across a transect of $90 \mathrm{~km}$ in Turkish Kurdistan in the first half of June 1979 (fig. 1, table 1). Out of this collection, 157 plants representing four populations were analyzed electrophoretically for 48 enzymatic loci. Locations and ecogeographical parameters are given in table 1 and the distribution of sites is mapped in fig. 1. The low number of populations analyzed here does not display minimization of sampling efforts. Rather, it emphatically displays the limited and isolated distribution of wild emmer in Turkish Kurdistan. Out of 20 localities in Turkish Kurdistan sampled for wild barley, $H$. spontaneum, only four localities involved wild emmer wheat (fig. 1).

\section{Electrophoresis}

Tissue preparative procedures and starch gel horizontal electrophoretic techniques, were similar to those used for wild barley (Brown et al., 1978). Locus and allele designations are as for the Israeli $T$. $t$. dicoccoides (Nevo et al., 1982). The 48 loci coding for the soluble proteins and their abbreviations are given below. The electrophoretic variants referred to in this paper as alleles, were labeled alphabetically in order of decreasing mobilities of their allozymes. We designated the first locus as A and the second one as B. Our A and $\mathrm{B}$ designations represent the two contributing diploid genomes, although they are not necessarily the same A and B genomes commonly designated so on cytogenetical grounds.

When only one genomic contribution was found, either letter was omitted. The loci code for acid phosphatases (EC 3.1.3.2) two loci (Acph-3; $A c p h-x)$; alcohol dehydrogenases (EC 1.1.1.1) four loci (Adh-1A,B; Adh-2A,B; catalases (EC 1.11.1.6) two loci (Cat-A,B); esterases (EC 3.1.1.2) six loci (Est-2A,B,; Est-4A,B; Est5A,B); glutamate dehydrogenases (EC 1.2.1.2) two loci ( $G d h-\mathrm{A}, \mathrm{B})$; glucosidase (EC 3.2.1.21) two loci (Gluc-A,B); aspartate aminotransferase (EC 2.6.1.1) six loci (Aat-1A,B;Aat-2A,B; Aat3A,B; previously Got); hexokinases (EC 2.7.1.1) one locus ( $H k$ ); indophenol oxidases (EC 1.10.3.1) three loci (Ipol; Ipor-A,B); malate dehydrogenases (EC 1.1.1.37) three loci $(M d h-1 \mathrm{~A}, \mathrm{~B} ; \quad M d h-2)$; lipoamide diaphorases (EC 1.6.4.3) four loci (Nadh-1A,B; Nadh-2A,B); phosphoenol pyruvate carboxylases (EC 4.1.1.31) one locus (Pepc); peptidases (EC 3.4.13.11) four loci (Pept-1A,B; Pept2; Pept-3); glucosephosphate isomerases (EC 5.3.1.9) two loci (Pgi-A,B); phosphoglucomutases (EC 2.7.5.1) two loci (Pgm-A,B); phosphogluconate dehydrogenases (EC 1.1.1.44) three loci (6Pgd-1A,B; 6Pgd-2); and shikimate dehydrogenase (EC 1.1.1.24) one locus (Skdh).

\section{Statistical analysis}

We used SPSS-x (1986) and SAS (1985) statistical packages, for conducting uni- and multivariate analyses.

\section{RESULTS}

\section{Pattern of variation}

Allele frequencies. Allele frequencies at 19 polymorphic loci out of the 48 loci tested appear in table 2. Nineteen systems exhibited both contributions from genomes A and B (38 loci, 79 per cent), whereas 10 loci (6Pgd-2, Mdh-2, Hk, Pepc, Acph-3, $A c p h-x$, Ipol, Pept-2, 3 and $S k d h)$ displayed only one genome, and we could not distinguish whether their complementary loci were silent or both genomes coincided in their banding. Activity of the homoeologous loci was not distinguishable in these cases. Our computed genetic values are therefore based on the assumption of 29 systems presumably encoded by 48 gene loci, i.e., these 10 loci were tentatively considered here as single loci. Although the variation we scored is real, its interpretation should be considered tentative until resolved by genetic crosses.

Out of 48 loci, 29 loci (60 per cent) were monomorphic for the same allele in all scorable populations (see table 2). Eight loci (17 per cent) were locally polymorphic (polymorphic in only one population out of four); 11 loci (23 per cent) were polymorphic in more than one population. In the monomorphic loci, and in the polymorphic groups, the same allele was either fixed or predominant in all four populations at 41 gene loci out of 48 . In the seven remaining loci $(M d h-2$, Pepc, Est-2A, 2B, 4B, 4B, Acph-x), as well as in six polymorphic loci, where the main allele predominated in all four populations ( $N a d h-2 \mathrm{~A}, G d h-\mathrm{A}, \mathrm{B}$, Adh-1A, Est-4A, Gluc-B), sharp genetic differentiation was displayed across the four populations, over the relatively short distance of $90 \mathrm{~km}$. 
Table 2 Allele frequencies and gene diversity $(\mathrm{He})$ at $48^{*}$ loci in four populations of $T$. $t$. dicoccoides, in Turkey

\begin{tabular}{|c|c|c|c|c|c|c|}
\hline \multicolumn{2}{|c|}{ Locus allele $\neq$} & $\begin{array}{c}\text { ion } \dagger \\
1 \\
39\end{array}$ & $\begin{array}{r}2 \\
45\end{array}$ & $\begin{array}{r}3 \\
48\end{array}$ & $\begin{array}{r}4 \\
25\end{array}$ & $\begin{array}{l}\text { Mean } \\
157\end{array}$ \\
\hline Acph-3 & $\begin{array}{l}\mathrm{a} \\
\mathrm{b} \\
\mathrm{He}\end{array}$ & $\begin{array}{l}0 \cdot 0 \\
1 \cdot 000 \\
0 \cdot 0\end{array}$ & $\begin{array}{l}0.0 \\
1 \cdot 000 \\
0 \cdot 0\end{array}$ & $\begin{array}{l}0 \cdot 0 \\
1 \cdot 000 \\
0 \cdot 0\end{array}$ & $\begin{array}{l}0.043 \\
0.957 \\
0.083\end{array}$ & $\begin{array}{l}0.006 \\
0.994 \\
0.021\end{array}$ \\
\hline Acph-x & $\begin{array}{l}\mathrm{a} \\
\mathrm{b} \\
\mathrm{He}\end{array}$ & $\begin{array}{l}1 \cdot 000 \\
0 \cdot 0 \\
0 \cdot 0\end{array}$ & $\begin{array}{l}0.425 \\
0.575 \\
0.489\end{array}$ & $\begin{array}{l}0.024 \\
0.976 \\
0.048\end{array}$ & $\begin{array}{l}0 \cdot 083 \\
0.917 \\
0 \cdot 153\end{array}$ & $\begin{array}{l}0.426 \\
0.574 \\
0.172\end{array}$ \\
\hline$A d h-1 \mathrm{~A}$ & $\begin{array}{l}\mathrm{a} \\
\mathrm{b} \\
\mathrm{He}\end{array}$ & $\begin{array}{l}1.000 \\
0 \cdot 0 \\
0 \cdot 0\end{array}$ & $\begin{array}{l}1 \cdot 000 \\
0 \cdot 0 \\
0 \cdot 0\end{array}$ & $\begin{array}{l}1.000 \\
0.0 \\
0.0\end{array}$ & $\begin{array}{l}0 \cdot 727 \\
0 \cdot 273 \\
0 \cdot 397\end{array}$ & $\begin{array}{l}0.978 \\
0.022 \\
0.099\end{array}$ \\
\hline Est $-2 \mathrm{~A}$ & $\begin{array}{l}\mathrm{a} \\
\mathrm{b} \\
\mathrm{c} \\
\mathrm{He}\end{array}$ & $\begin{array}{l}0.0 \\
0.350 \\
0.650 \\
0.455\end{array}$ & $\begin{array}{l}0.156 \\
0.438 \\
0.406 \\
0.619\end{array}$ & $\begin{array}{l}0.063 \\
0.125 \\
0.813 \\
0.320\end{array}$ & $\begin{array}{l}- \\
- \\
-\end{array}$ & $\begin{array}{l}0.074 \\
0.303 \\
0.622 \\
0.465\end{array}$ \\
\hline Est-2B & $\begin{array}{l}\mathrm{c} \\
\mathrm{d} \\
\mathrm{e} \\
\mathrm{He}\end{array}$ & $\begin{array}{l}0 \cdot 217 \\
0 \cdot 783 \\
0 \cdot 0 \\
0 \cdot 340\end{array}$ & $\begin{array}{l}0 \cdot 0 \\
0 \cdot 148 \\
0 \cdot 852 \\
0.252\end{array}$ & $\begin{array}{l}0.0 \\
0 \cdot 0 \\
1.000 \\
0.0\end{array}$ & $\begin{array}{l}- \\
- \\
-\end{array}$ & $\begin{array}{l}0.065 \\
0.286 \\
0.649 \\
0.198\end{array}$ \\
\hline Est $-4 \mathrm{~A}$ & $\begin{array}{l}\mathrm{a} \\
\text { null }(-) \\
\mathrm{He}\end{array}$ & $\begin{array}{l}1.000 \\
0.0 \\
0.0\end{array}$ & $\begin{array}{l}1 \cdot 000 \\
0.0 \\
0.0\end{array}$ & $\begin{array}{l}0 \cdot 781 \\
0 \cdot 219 \\
0 \cdot 342\end{array}$ & $\frac{-}{-}$ & $\begin{array}{l}0.919 \\
0.081 \\
0.114\end{array}$ \\
\hline Est-4B & $\begin{array}{l}\mathrm{b} \\
\mathrm{c} \\
\mathrm{He}\end{array}$ & $\begin{array}{l}0.513 \\
0.487 \\
0.500\end{array}$ & $\begin{array}{l}0.198 \\
0.802 \\
0.317\end{array}$ & $\begin{array}{l}0.125 \\
0.875 \\
0.219\end{array}$ & $\frac{-}{-}$ & $\begin{array}{l}0.265 \\
0.735 \\
0.345\end{array}$ \\
\hline Est-5A & $\begin{array}{l}\text { a } \\
\text { null } \\
\mathrm{He}\end{array}$ & $\begin{array}{l}0.974 \\
0.026 \\
0.050\end{array}$ & $\begin{array}{l}1 \cdot 000 \\
0 \cdot 0 \\
0 \cdot 0\end{array}$ & $\begin{array}{l}1.000 \\
0.0 \\
0.0\end{array}$ & $\begin{array}{l}1.000 \\
0 \cdot 0 \\
0.0\end{array}$ & $\begin{array}{l}0.993 \\
0.007 \\
0.012\end{array}$ \\
\hline Est $-5 \mathrm{~B}$ & $\begin{array}{l}\mathrm{a}=\text { null } \\
\mathrm{c} \\
\mathrm{e} \\
\mathrm{He}\end{array}$ & $\begin{array}{l}0.846 \\
0 \cdot 154 \\
0 \cdot 0 \\
0 \cdot 260\end{array}$ & $\begin{array}{l}0 \cdot 216 \\
0 \cdot 784 \\
0 \cdot 0 \\
0 \cdot 339\end{array}$ & $\begin{array}{l}0.405 \\
0.405 \\
0.190 \\
0.636\end{array}$ & $\begin{array}{l}0.080 \\
0.440 \\
0.480 \\
0.570\end{array}$ & $\begin{array}{l}0.420 \\
0.441 \\
0 \cdot 140 \\
0.451\end{array}$ \\
\hline$G d h-\mathrm{A}$ & $\begin{array}{l}\mathrm{a}(-) \\
\mathrm{b}(\mathrm{a}) \\
\mathrm{He}\end{array}$ & $\begin{array}{l}0.308 \\
0.692 \\
0.426\end{array}$ & $\begin{array}{l}0 \cdot 0 \\
1 \cdot 000 \\
0 \cdot 0\end{array}$ & $\begin{array}{l}0 \cdot 229 \\
0 \cdot 771 \\
0 \cdot 353\end{array}$ & $\begin{array}{l}0 \cdot 0 \\
1.000 \\
0 \cdot 0\end{array}$ & $\begin{array}{l}0.146 \\
0 \cdot 854 \\
0 \cdot 195\end{array}$ \\
\hline$G d h-\mathrm{B}$ & $\begin{array}{l}\mathrm{b}(\mathrm{a}) \\
\text { null }(-) \\
\mathrm{He}\end{array}$ & $\begin{array}{l}0.692 \\
0.308 \\
0.426\end{array}$ & $\begin{array}{l}1 \cdot 000 \\
0 \cdot 0 \\
0 \cdot 0\end{array}$ & $\begin{array}{l}0 \cdot 771 \\
0 \cdot 229 \\
0.353\end{array}$ & $\begin{array}{l}1.000 \\
0.0 \\
0.0\end{array}$ & $\begin{array}{l}0.854 \\
0.146 \\
0.195\end{array}$ \\
\hline Gluc-B & $\begin{array}{l}\mathrm{b} \\
\mathrm{c} \\
\mathrm{He}\end{array}$ & $\begin{array}{l}0 \cdot 846 \\
0 \cdot 154 \\
0 \cdot 260\end{array}$ & $\begin{array}{l}0 \cdot 867 \\
0 \cdot 133 \\
0 \cdot 231\end{array}$ & $\begin{array}{l}1.000 \\
0.0 \\
0.0\end{array}$ & $\begin{array}{l}1.000 \\
0.0 \\
0.0\end{array}$ & $\begin{array}{l}0.923 \\
0.077 \\
0.123\end{array}$ \\
\hline Ipor-B & $\begin{array}{l}\mathrm{a} \\
\mathrm{b} \\
\mathrm{He}\end{array}$ & $\begin{array}{l}1.000 \\
0.0 \\
0.0\end{array}$ & $\begin{array}{l}1.000 \\
0 \cdot 0 \\
0.0\end{array}$ & $\begin{array}{l}1 \cdot 000 \\
0 \cdot 0 \\
0 \cdot 0\end{array}$ & $\begin{array}{l}0.960 \\
0.040 \\
0.077\end{array}$ & $\begin{array}{l}0.994 \\
0.006 \\
0.019\end{array}$ \\
\hline$M d h-2$ & $\begin{array}{l}\mathrm{a}(-) \\
\mathrm{b}(\mathrm{a}) \\
\mathrm{d}(-) \\
\mathrm{He}\end{array}$ & $\begin{array}{l}0.013 \\
0.987 \\
0.0 \\
0.025\end{array}$ & $\begin{array}{l}0.0 \\
1.000 \\
0.0 \\
0.0\end{array}$ & $\begin{array}{l}0.073 \\
0.927 \\
0.0 \\
0.135\end{array}$ & $\begin{array}{l}0.0 \\
0.440 \\
0.560 \\
0.493\end{array}$ & $\begin{array}{l}0.025 \\
0.885 \\
0.089 \\
0.163\end{array}$ \\
\hline Nadh-1A & $\begin{array}{l}\mathrm{b} \\
\mathrm{c} \\
\mathrm{He}\end{array}$ & $\begin{array}{l}1 \cdot 000 \\
0 \cdot 0 \\
0 \cdot 0\end{array}$ & $\begin{array}{l}0 \cdot 889 \\
0 \cdot 111 \\
0 \cdot 198\end{array}$ & $\begin{array}{l}1 \cdot 000 \\
0.0 \\
0 \cdot 0\end{array}$ & $\begin{array}{l}1.000 \\
0.0 \\
0.0\end{array}$ & $\begin{array}{l}0.968 \\
0.032 \\
0.049\end{array}$ \\
\hline Nadh-2A & $\begin{array}{l}\mathrm{a}(-) \\
\mathrm{b}(\mathrm{a}) \\
\mathrm{He}\end{array}$ & $\begin{array}{l}0.436 \\
0.564 \\
0.492\end{array}$ & $\begin{array}{l}0.0 \\
1 \cdot 000 \\
0.0\end{array}$ & $\begin{array}{l}0.042 \\
0.958 \\
0.080\end{array}$ & $\begin{array}{l}0 \cdot 0 \\
1 \cdot 000 \\
0 \cdot 0\end{array}$ & $\begin{array}{l}0.121 \\
0.879 \\
0.143\end{array}$ \\
\hline
\end{tabular}


Table 2 continued

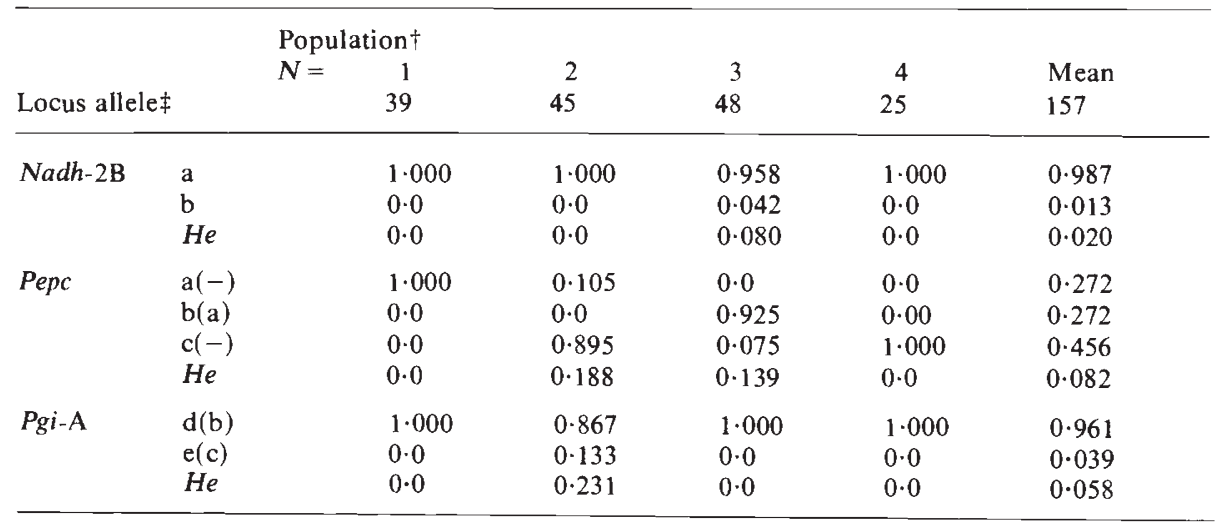

* List of the 29 monomorphic loci, and the designation of their alleles: Aat-1A b, Aat-1B a, Aat-2A b, Aat-2B a, Aat-3A a, Aat-3B a, Adh-1B b, Adh-2A a, Adh-2B a, Cat-A a, Cat-B a, Gluc-A a, $H k b(\mathrm{a}), I p o l \mathrm{~b}, I p o r-\mathrm{A}$ a, Mdh-1A b, Mdh-1B a, Nadh-1B b(a),Pept-1A a,Pept-1B a,Pept-2b, Pgi-B a, Pgm-A b, Pgm-B a, 6Pgdh-1A a, 6Pgdh-1B b(a), 6 Pgdh-2 a, $S k d h$ a.

$\dagger$ Population numbers refer to those listed in table 1 .

\$Allele designation (in parenthesis) in Nevo et al. (1982).

The designation of the alleles of Est-2A, B and -5A, B is entirely new.

Genetic summary. A summary of genetic data of the four populations of T. t. dicoccoides in Turkey is given in table 3 . The genetic indices are calculated separately for (i) all 48 loci tested; (ii) 41 shared loci (i.e., scorable in all four Turkish populations) and, (iii) 37 loci also shared with Israeli populations calculated for future comparisons, and (iv) 41 loci in all four Turkish populations considered as a megapopulation. Most further analyses, unless otherwise specified, were conducted on the data-set of the 41 shared loci.

The major features were: (a) Levels of genetic diversity were medium, (compare with mean value of $\mathrm{He}=0.083$ of 110 species in Nevo et al., 1984). (b) The genetic indices, based on the 41 shared loci, were similar among the four populations. However, the estimates based on 48 loci involved the average number of alleles per locus, $A$ (mean $1 \cdot 215$, range $1 \cdot 171-1 \cdot 271$ ); the proportion of polymorphic loci per population, $P-1$ per cent (mean $0 \cdot 193$, range $0 \cdot 146-0 \cdot 229)$; and the proportion of heterozygosity per locus per individual, $H$ (mean 0.0005 , range $0 \cdot 000-0 \cdot 001$ ). The mean index of genic diversity, $\mathrm{He}$, which is the average per locus probability that two random gametes from the population carry different alleles at a locus (Nei, 1975 ), was $0 \cdot 057$, range $0 \cdot 043-0 \cdot 067$. The mean of Wright's fixation index (Wright, 1965) was very high $(F=0.99$, range $0.982-1 \cdot 00)$. The estimates of $H$ and $F$ imply that $T$. $t$. dicoccoides is predominantly seif pollinated, with outcrossing of the order of 1 per cent (compare with estimates of less than 1 per cent deduced from field and experimental garden material by Golenberg, 1986).

The overall number of alleles detected in the 48 loci in the four populations of $T$. $t$. dicoccoides in Turkey amount to 72 (mean per locus $1 \cdot 50$, range 1-3) (compare with the estimate of 110 alleles found in Israeli $T$. $t$. dicoccoides in Nevo et al., 1982: 248).

Geographic patterns of allele distribution. Regional distribution of minor alleles ( $<50$ per cent) of polymorphic loci (appearance in two or more populations) included: $M d h-2^{\mathrm{a}}, N a d h-2 \mathrm{~A}^{\mathrm{a}}, G d h-$ $\mathrm{A}^{\mathrm{a}}, G d h-\mathrm{B}^{\text {null }}, P e p c^{\mathrm{a}}, P e p c^{\mathrm{c}}, E s t-4 \mathrm{~B}^{\mathrm{b}}$, Est $-5 \mathrm{~B}^{\mathrm{a}}$, Est $5 \mathrm{~B}^{\mathrm{c}}$, Est $-5 \mathrm{~B}^{\mathrm{e}}$, Acph-x $\mathrm{x}^{\mathrm{a}}$, Gluc- $\mathrm{B}^{\mathrm{c}}$, Est $-2 \mathrm{~A}^{\mathrm{a}}$, Est $-2 \mathrm{~A}^{\mathrm{b}}$, Est-2B ${ }^{\mathrm{d}}$. Local distribution (appearance in only one population) included: $P g i-\mathrm{A}^{\mathrm{e}}, \mathrm{Mdh}-2^{\mathrm{d}}, \mathrm{Nadh}$ $1 \mathrm{~A}^{\mathrm{c}}, I$ IporB $B^{\mathrm{b}}, A d h-1 \mathrm{~A}^{\mathrm{b}}, E s t-4 \mathrm{~A}^{\text {null }}$, Est $-5 \mathrm{~A}^{\text {null }}, A c p h-$ $3^{a}$, Est $-2 \mathrm{~B}^{c}, P e p c^{\mathrm{b}}, N a d h-2 \mathrm{~B}^{\mathrm{b}}$.

To assess the various kinds of allele distribution we followed the classification proposed by Marshall and Brown (1975). Each of the 72 alleles found in the four populations of $T$. $t$. dicoccoides in Turkey was classified into one of the following classes: (i) Common: (at least one population with frequency $>10$ per cent); (a,b) widespread and 
Table 3 Summary of genetic diversity based on (A) 48 loci (all), (B) 41 loci (shared in Turkey) and (C) 37 loci (shared with Israel) of $T$. $t$. dicoccoides in four populations in Turkey, and (D) as a megapopulation, based on 41 loci

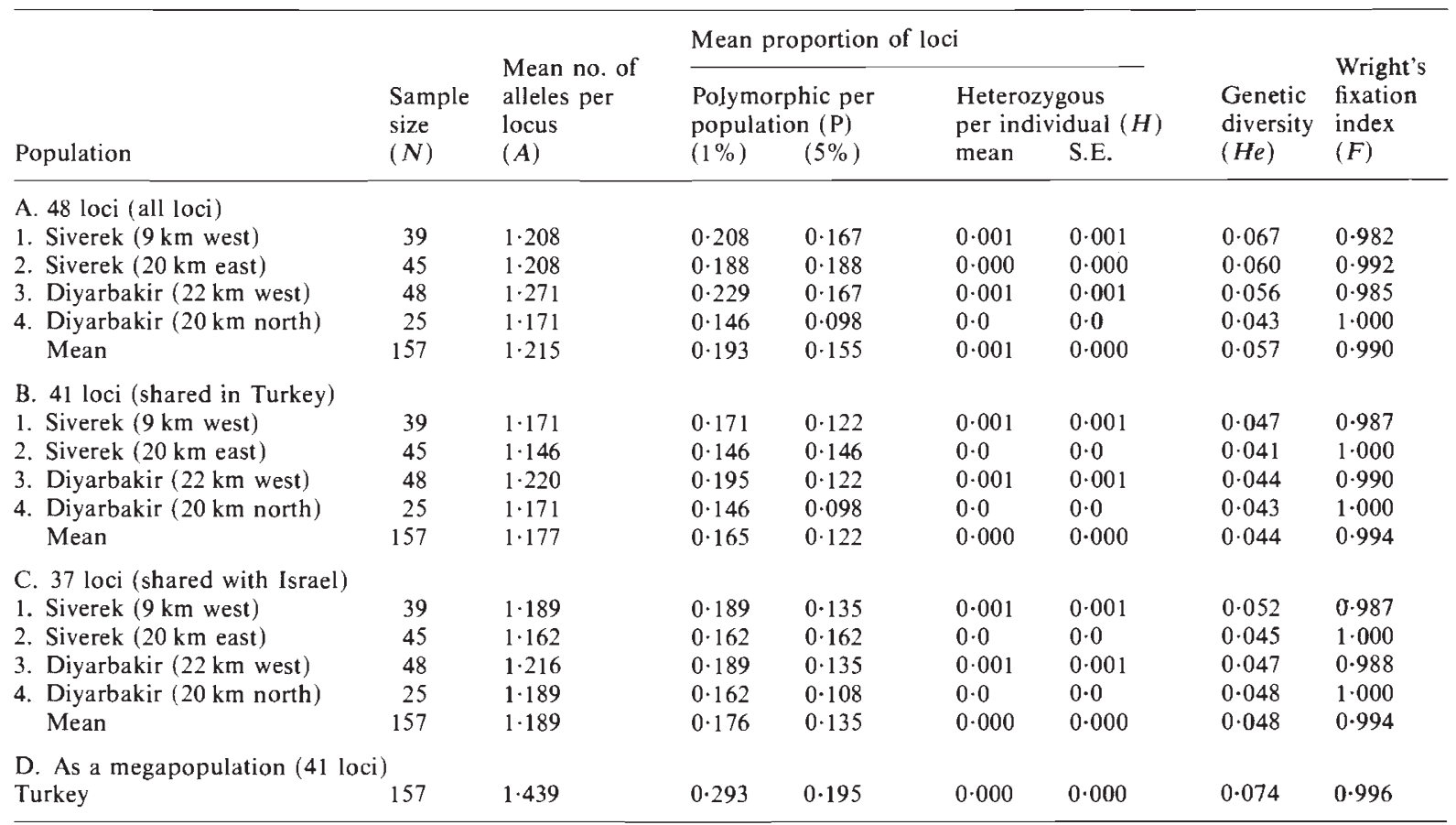

sporadic (combined due to low number of populations): common occurrence in two or more populations (58 alleles or 42 per cent of the variant alleles); and (c) localized: common occurrence in only one population (nine alleles, or 37 per cent); (ii) Rare: (never occurs with frequency $>10$ per cent); (d) widespread: in more than one population (one allele, or 4 per cent); and (e) localized: in only one population (four alleles, or 17 per cent). The percentage of the variants was computed by subtracting the number of loci studied from the number of alleles in class (i) (a). This adjustment standardized any difference in the number of invariant loci recorded. Note that 13 of the 24 variant alleles, or 54 per cent, were localized or sporadic.

Genetic distance. Coefficients of genetic similarity $(I)$, and distance $(D)$, were calculated for paired comparisons of the four populations, based on the normalized identity of all loci between each pair of populations (Nei, 1972). The results are given in table 4 . The mean value of $D$, for the 41 shared loci, was $0 \cdot 046$, range, $0 \cdot 019-0 \cdot 082$. The standard' errors of the individual values of $D$ were equal or less than 0.005 . The estimates of $D$ indicate sharp genetic differentiation over short geographic distances.
Discriminant analysis. We conducted stepwise discriminant analysis (SPSS-x 1986) maximizing the overall multivariate $F$ ratio of the four populations. The analysis was based on a multilocus analysis involving 13 polymorphic loci and 19 alleles. From these the program chose nine alleles out of seven

Table 4 Coefficients of genetic similarity ( $I$, upper figure), and genetic distance ( $D$, middle figure) with standard error (lower figure) between four populations of $T$. $t$. dicoccoides in Turkey, based on 41 loci

\begin{tabular}{|c|c|c|c|c|}
\hline Population & 1 & 2 & 3 & 4 \\
\hline $\begin{array}{l}\text { 1. Siverek } \\
(9 \mathrm{~km} \text { west })\end{array}$ & & $\begin{array}{l}0.951 \\
0.051 \\
0.004\end{array}$ & $\begin{array}{l}0.943 \\
0.059 \\
0.002\end{array}$ & $\begin{array}{l}0.921 \\
0.082 \\
0.005\end{array}$ \\
\hline $\begin{array}{l}\text { 2. Siverek } \\
(20 \mathrm{~km} \text { east })\end{array}$ & & & $\begin{array}{l}0.969 \\
0.031 \\
0.002\end{array}$ & $\begin{array}{l}0.981 \\
0.019 \\
0.003\end{array}$ \\
\hline $\begin{array}{l}\text { 3. Diyarbakir } \\
(22 \mathrm{~km} \text { west })\end{array}$ & & & & $\begin{array}{l}0.964 \\
0.037 \\
0.003\end{array}$ \\
\hline
\end{tabular}

4. Diyarbakir (20 km north)
I: Mean 0.955
Range 0.921-0.981
$D$ : Mean 0.046
Range 0.019-0.082 
loci as the best differentiating factors $\left(P e p c^{\mathrm{a}, \mathrm{c}}\right.$, $M d h-2^{\mathrm{d}}$, Est $-5 \mathrm{~B}^{\mathrm{c}}$, Gluc- $\mathrm{B}^{\mathrm{c}}$, Ipor $-\mathrm{B}^{\mathrm{b}}, N a d h-2 \mathrm{~A}^{\mathrm{a}}$, $G d h-\mathrm{A}^{\mathrm{a}}$, Est $-5 \mathrm{~B}^{\mathrm{e}}$, table $\left.5 \mathrm{~B}\right)$. We selected the preliminary 13 out of the 19 polymorphic loci tested in order to minimize the reduction of sample size for this analysis due to missing data. The results are given in fig. 2 and table 5.

The analysis succeeded to differentiate significantly between plants from the four popula- tions by pairwise comparison $(\mathrm{F}=14-137: \mathrm{df}=$ 9/103 $p<0.001$ : table 5A) and by three significant canonical discriminant function (table $5 \mathrm{C}$ and fig. 2 ). The correct classification of plants into their four populations was 86 per cent (101 out of 117 analyzed plants, table 5D). Notably, populations 1-3 were correctly classified between $90-100$ per cent, and only population No. 4 displayed a lower discrimination of 60 per cent.

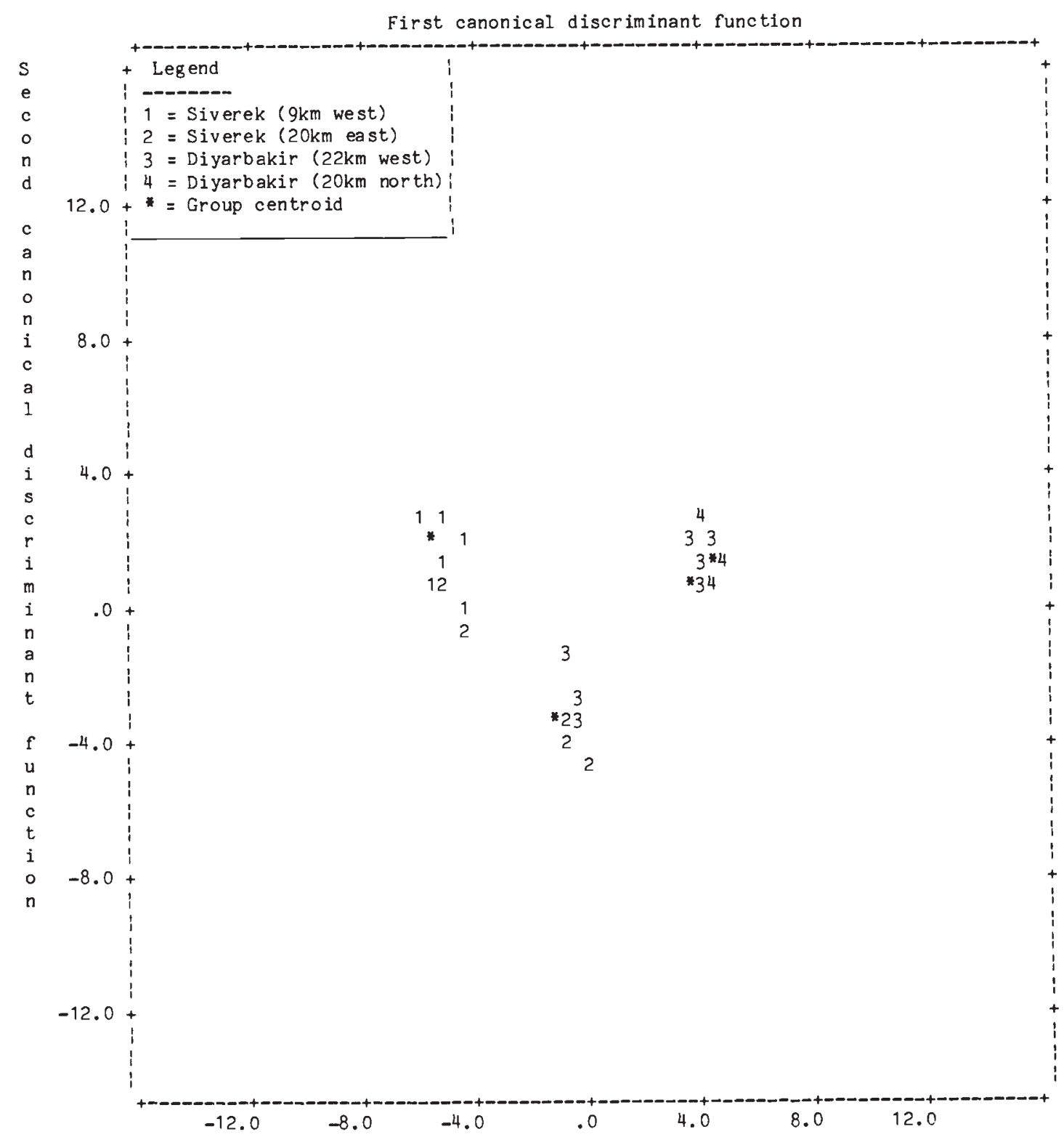

Figure 2 Discriminant analysis of wild emmer wheat of four populations of $T$. $t$. dicoccoides in Turkey, based on 8 polymorphic allozyme loci and 10 alleles. Note that each point on the diagram represents different numbers of genetically similar plants. 
Table 5 Stepwise discriminant analysis of genetic diversity of $T$. $t$. dicoccoides between four populations in Turkey

A. Pairwise comparison between four populations

The $F$ statistic has 9 and 103 degrees of freedom.

$N=115$ (out of 157 ); 31, 31, 30 and 23 for populations no. 1, 2, 3 and 4 , respectively.

\begin{tabular}{llccc}
\hline Population: & & $\begin{array}{l}1 \\
\text { Siverek } \\
9 \mathrm{~km} \text { west }\end{array}$ & $\begin{array}{l}2 \\
\text { Siverek } \\
20 \mathrm{~km} \text { east }\end{array}$ & $\begin{array}{l}3 \\
\text { Diyarbakir } \\
22 \mathrm{~km} \text { west }\end{array}$ \\
\hline 2. Siverek & $\mathrm{F}=$ & 77.512 & & \\
$20 \mathrm{~km}$ east & $\mathrm{p}=$ & 0.0000 & & \\
3. Diyarbakir & $\mathrm{F}=$ & 131.74 & 66.552 & \\
$22 \mathrm{~km}$ east & $\mathrm{p}=$ & 0.0000 & 0.0000 & 14.145 \\
4. Diyarbakir & $\mathrm{F}=$ & 133.77 & 71.356 & 0.0000 \\
$20 \mathrm{~km}$ north & $\mathrm{p}=$ & 0.0000 & 0.0000 &
\end{tabular}

B. Summary table (Chosen variables)

\begin{tabular}{|c|c|c|c|c|c|}
\hline Step & $\begin{array}{l}\text { Action } \\
\text { Entered }\end{array}$ & Removed & $\begin{array}{l}\text { Variables } \\
\text { in }\end{array}$ & $\begin{array}{l}\text { Wilks' } \\
\text { Lambda }\end{array}$ & Significance \\
\hline 1 & $P e p c$ a & & 1 & 0.09554 & $0 \cdot 0000$ \\
\hline 3 & $M d h-2 \mathrm{~d}$ & & 3 & 0.00938 & 0.0000 \\
\hline 4 & Est-5B C & & 4 & 0.00705 & 0.0000 \\
\hline 5 & Gluc-B c & & 5 & 0.00652 & 0.0000 \\
\hline 8 & $G d h-\mathrm{A}$ a & & 8 & 0.00508 & 0.0000 \\
\hline 9 & $E s t-5 \mathrm{~B} \mathrm{e}$ & & 9 & 0.00468 & 0.0000 \\
\hline
\end{tabular}

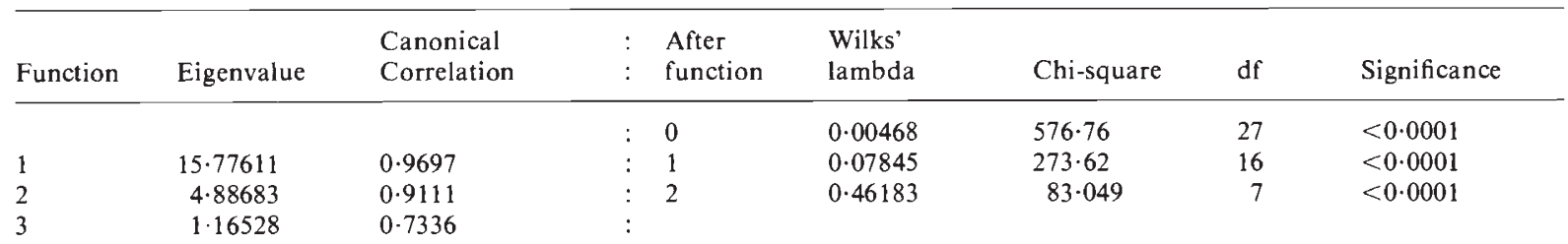

D. Classification results

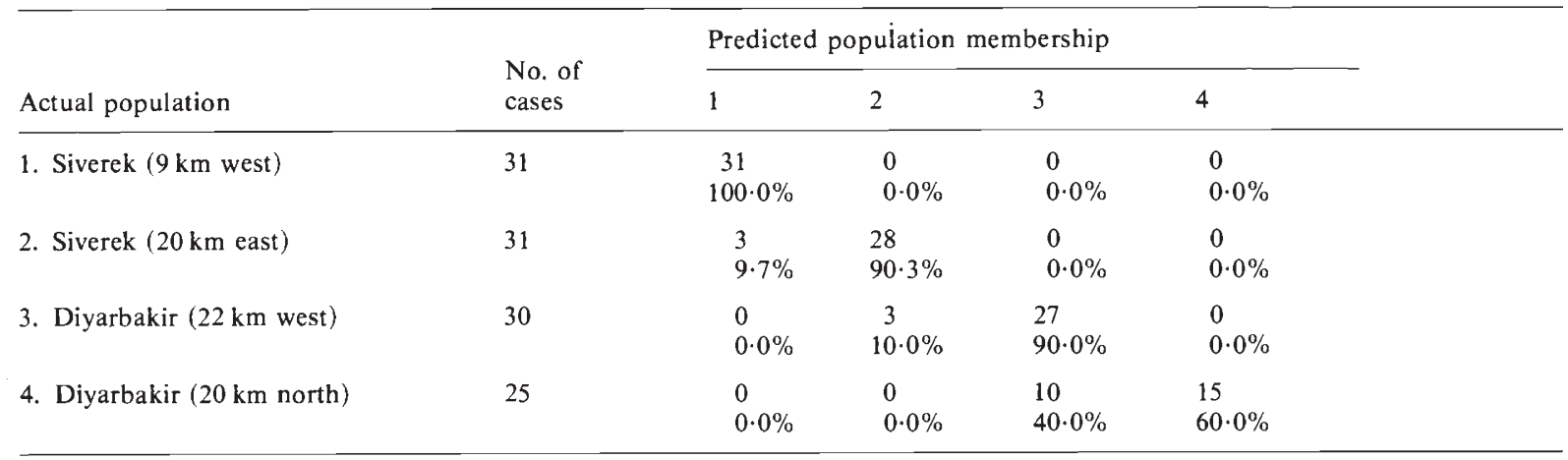

86.55 per cent of plants were correctly classified. 


\section{Environmental correlates with} allozyme polymorphisms

Correlation among environmental variables and among genetic indices. In our search for environmental correlates with allozyme variation, we used several variables: Geographical: longitude ( $\mathrm{Ln})$, latitude ( $\mathrm{Lt}$ ) and altitude ( $\mathrm{Al})$, and Climatic: temperature (mean annual, Tm, mean January, $\mathrm{Tj}$, mean August, Ta.), moisture (mean annual rainfall, $\mathrm{Rn}$, mean relative humidity, $\mathrm{Hu}$ ). Among the environmmental variables, water and temperature were highly and significantly correlated (i.e., Rn$\left.\mathrm{Tm}, r_{\mathrm{s}}=1 \cdot 00\right)$. All temperature variables also displayed high intercorrelations $\left(r_{\mathrm{s}}=1 \cdot 00\right)$. Among the genetic indices the highest Spearman rank correlation was between $P-1$ per cent and $A\left(r_{\mathrm{s}}=\right.$ $0 \cdot 83)$, and with $\mathrm{He}\left(r_{\mathrm{s}}=0 \cdot 74\right)$.

Correlations between genetic indices, allele frequencies and climatic variables. Six of 29 alleles (21 per cent) approach significant ecogeographical correlates. This may be due to the low number of populations, so that even correlations of $r_{\mathrm{s}}=1.00$ are not significant. We therefore ran a multiple regression analysis to unravel any climatic associations based on several-variable combinations.

Multiple regression analysis. A test of the best predictors of $P-1$ per cent, $P-5$ per cent, $\mathrm{He}$, and representative six allele frequencies at five polymorphic loci, was conducted by stepwise multiple linear regression analysis employing these characters as dependent variables. Geographic and cli-

Table 6 Coefficients of multiple regressions $\left(R^{2}\right)$ of genic diversity $(\mathrm{He})$ and six allele frequencies (after arcsine transformation) as the dependent variables and geographic and climatic variables in four populations of $T$. $t$. dicoccoides in Turkey as independent variables (for abbreviations see table 1)

\begin{tabular}{lll}
\hline & Stepwise & Model \\
\hline He & Ta & Ta Al \\
Mdh-2 b & $0.909^{*}$ & $0.996 \dagger$ \\
& $\mathrm{Ln}$ & $\mathrm{Ln} \mathrm{Al}$ \\
Nadh-2A b & $0.867 \dagger$ & $0.9997^{*}$ \\
& $\mathrm{Ta}$ & $\mathrm{Ta} \mathrm{Lt}$ \\
Gdh-A a & $0.728 \mathrm{~ns}$ & $1.000^{* *}$ \\
& $\mathrm{Lt}$ & $\mathrm{Lt} \mathrm{Ln}$ \\
Pepc c & $0.615 \mathrm{~ns}$ & $0.961 \mathrm{~ns}$ \\
& $\mathrm{Al}$ & \\
Est-5B c & $0.758 \mathrm{~ns}$ & \\
& $\mathrm{Ln}$ & $\mathrm{Ln} \mathrm{Ta}$ \\
Est $-5 \mathrm{~B}$ e & $0.914^{*}$ & $0.992 \dagger$ \\
& Ta & Ta Hu \\
& $0.941^{*}$ & $0.9995^{*}$ \\
\hline
\end{tabular}

Level of significance: ${ }^{* *}=p<0 \cdot 01 ; *=p<0 \cdot 05 ; \dagger=p<0 \cdot 10$; $\mathrm{ns}=p>0 \cdot 10$. matic variables were employed as independent variables. The results are given in table 6 . Genetic diversity, as estimated by $\mathrm{He}$, and of several representative alleles was explained by ecogeographic factors. Foremost, $\mathrm{He}$, was largely explained by a 2-variable combination of mean August temperature and altitude $\left(R^{2}=0.996, p<0.05\right)$. Likewise, mean August temperature, annual humidity, longitude and latitude explain significantly the variance in several allele frequencies (table 6).

\section{Genetic differentiation within and among populations}

Gene diversity of a subdivided population $(\mathrm{Ht})$ can be analyzed into its components: measures of the average (Dst) and relative (Gst) degree of gene differentiation among subpopulations; where $H s$ is the mean gene diversity in a population and $\mathrm{Ht}$ is the total diversity, and $H t=H s+D s t$ (Nei, 1973). Table 7 summarizes the estimates of the diversity $(H t)$ and the proportion expressed between populations (Gst) for each locus. The average total genic diversity across all 48 loci of T. t. dicoccoides in Turkey was $H t=0.096$ (ranging from 0.0 to 0.69 ). Ten loci were markedly variable, four loci were near or below average, and five loci were weakly polymorphic. It should be noted that the $H t$ values were distributed discontinuously. The average relative differentiation among populations in Turkey among 19 polymorphic loci was $G s t=0.37$ (ranging from 0.019 to $0 \cdot 855$ ). In other words, 63 per cent of the allozymic variation was within and 37 per cent was between populations. The highest interpopulation differentiation was displayed by the following loci: Pepc, Acph-x, Est-2B, Est-5B, Mdh-2 and Nadh$2 \mathrm{~A}$.

\section{Genetic differentiation at the two-locus level: gametic phase disequilibria}

Examples of gametic phase disequilibria $(D)$ for the entire sample and for each population are given in table 8 . Notably, a considerable amount of significant gametic phase disequilibria occurs in one or more populations, as well as in the entire sample, above that which may be expected by chance.

\section{Multilocus organization}

Multilocus organization index, related to the single-locus Simpson Index, and based on the observed distribution of the number of heterozy- 
Table 7 Partition of genetic diversity of $T$. $t$. dicoccoides within and between four populations in Turkey, based on 48 polymorphic loci (Gst analysis; Nei, 1973)

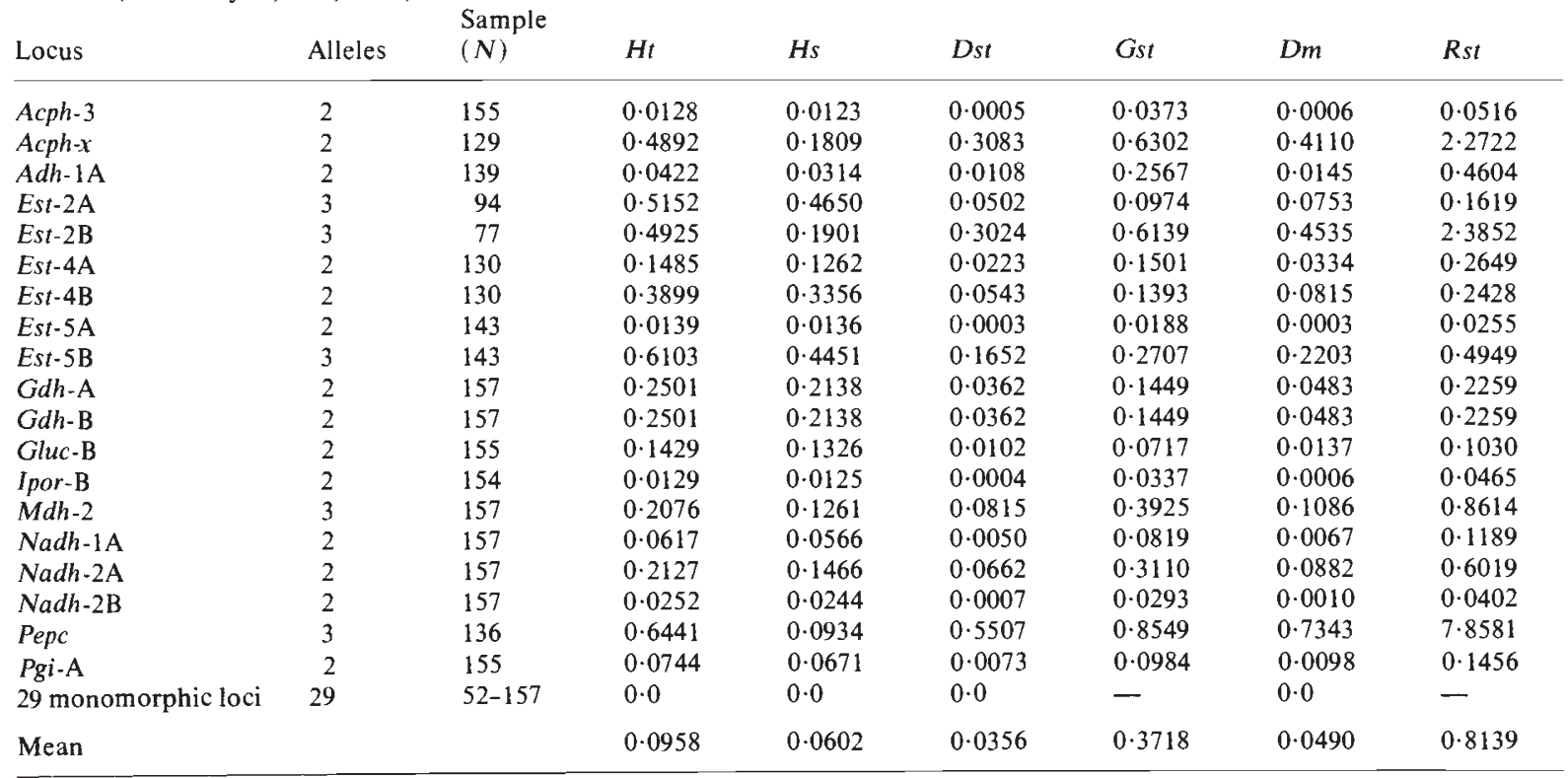

Abbreviations: $H t=$ Total gene diversity, $H s=$ Average gene diversity within populations, Dst = Average gene diversity between populations, $D m=$ Average of interpopulation diversity only, Gst $=$ Gene diversity between populations, relative to $H t$, $R s t=$ Interpopulational diversity, relative to $H s$.

gous loci $(K)$ in two randomly chosen gametes, was proposed by Brown et al. (1980). It measures multilocus associations when multiple alleles and many loci are analyzed, combining all paired-loci gametic-phase-disequilibria. We calculated multilocus organization indices for the entire data set and for each population in this study separately. The results are given in table 9. The differences between the expected and observed variances of $K$ are significant in populations Nos. 1, 3, 4 and in the megapopulation. The observed variance of $K$ in the entire data set was 71 per cent above the expected. The ranking of the measure of intensity of multilocus association $X(2)$ of the four populations was $29,85,98$ and 125 per cent for populations 2, 3, 4 and 1, respectively (table 9).

\section{DISCUSSION}

Basically, the patterns of genetic diversity and differentiation of wild emmer wheat in Turkey were similar to the patterns previously found in Israel (Nevo et al., 1982). T. t. dicoccoides in Turkey is characterized by the following features. (i) The levels of genetic diversity for 48 loci were medium (He $=0.057$, range $0.043-0.067)$ as compared with the average $H e=0.070$ of Israeli $T$. $t$. dicoccoides, based on 50 gene loci (Nevo et al., 1982), and average $\mathrm{He}=0.083$ of 1100 species analyzed by Nevo et al., (1984). (ii) Altogether there were 72 alleles at the 48 putative loci tested in the four Turkish populations, as compared with 110 alleles at the 50 loci tested in 12 Israeli populations. The lower number of alleles in Turkey may be sample dependent, and/or may derive from the exclusion of the highly polymorphic Est-1A,B in the analysis of the Turkish populations due to nonscorability. (iii) Sharp genetic differentiation occurred in some of the polymorphic loci over small geographic distances. (iv) Relatively high genetic distances occurred between geographically close populations (mean $D=0.046$, range, $0.019-0.082$ ) as compared with $D=0.097$, range $0.023-0.248$, in 12 Israeli populations extending over about a doublefold geographic transect, and a broader ecological spectrum (Nevo et al., 1982). (v) Localized alleles were frequent: 54 per cent in Turkey as compared with 45 per cent in Israel. (vi) Rare alleles were few, five in both Turkey and Israel, 6.9 per cent and 4.5 per cent, respectively. (vii) A substantial amount of the genetic diversity ( 37 per cent) was between the four populations. (viii) The patterns of $\mathrm{He}$ and frequencies of several alleles 
Table 8 Representative gametic phase disequilibria $(D)$ between paired loci of $T$. $t$. dicoccoides in Turkey; in the entire sample, and separately for each population

\begin{tabular}{|c|c|c|c|c|c|c|}
\hline \multirow[b]{2}{*}{$\begin{array}{l}\text { Locus and } \\
\text { Allele }\end{array}$} & \multirow[b]{2}{*}{$\begin{array}{l}\text { Locus and } \\
\text { Allele }\end{array}$} & \multirow[b]{2}{*}{$\begin{array}{l}\text { Over all } \\
p\end{array}$} & \multicolumn{4}{|l|}{ Population } \\
\hline & & & $\begin{array}{l}\text { 1. Siverek } \\
(9 \mathrm{~km} \mathrm{~W}) p\end{array}$ & $\begin{array}{l}\text { 2. Siverek } \\
(20 \mathrm{~km} \mathrm{E}) p\end{array}$ & $\begin{array}{l}\text { 3. Diyarbakir } \\
(22 \mathrm{~km} \mathrm{~W}) p\end{array}$ & $\begin{array}{l}\text { 4. Diyarbakir } \\
(20 \mathrm{~km} \mathrm{~N}) p\end{array}$ \\
\hline Nadh-1A b & $A c p h-x$ a & $-0.022^{*}(\mathrm{c})$ & - & $-0.072^{* *}$ (c) & - & - \\
\hline$N a d h-1 \mathrm{~A}$ b & Est-2A b & 0.016 ns (c) & - & $0.068+(\mathrm{c})$ & - & \\
\hline$N a d h-2 \mathrm{~A}$ a & $G d h-\mathrm{A}$ a & $-0.018 \mathrm{~ns}(\mathrm{c})$ & $-0 \cdot 134^{* * *}(\mathrm{c})$ & - & $-0.010 \mathrm{~ns}(\mathrm{c})$ & - \\
\hline$N a d h-2 \mathrm{~A}$ a & Est-2A b & $-0.028 \mathrm{~ns}$ & $-0.083 \mathrm{~ns}$ & - & $-0.008 \mathrm{~ns}(\mathrm{c})$ & \\
\hline$G d h-\mathrm{A}$ a & $G d h-\mathrm{B}$ b & $-0 \cdot 125^{* * *}$ (a) & $-0.213^{* * *}$ (a) & - & $-0.177^{* * *}$ (a) & - \\
\hline$G d h-\mathrm{A}$ a & Est-4A a & $-0.036^{* *}$ & - & - & $-0.085^{* *}$ & \\
\hline$G d h-\mathrm{A}$ a & Est-4B b & $0.045^{* *}$ & $0 \cdot 150^{* * *}(\mathrm{c})$ & - & $-0.029 \mathrm{~ns}(\mathrm{c})$ & \\
\hline$G d h-\mathrm{A}$ a & Est $-5 \mathrm{~B} \mathrm{e}$ & $0.019 \mathrm{~ns}$ & - & - & $0.093^{* *}$ & - \\
\hline$G d h-\mathrm{A}$ a & Est-2B d & $0.056^{*}$ & $0.076 \mathrm{~ns}(\mathrm{c})$ & - & - & \\
\hline Est-2A b & Est-2B d & $0.051^{\dagger}$ & $0.056 \mathrm{~ns}$ & $-0.003 \mathrm{~ns}$ & - & \\
\hline$A c p h-x$ a & Est-2A b & $0.015 \mathrm{~ns}$ & - & $-0.085 \mathrm{~ns}$ & $-0.005 \mathrm{~ns}$ & \\
\hline Acph-x a & Est-2B d & $0.079^{* *}$ & - & $-0.088^{*}(\mathrm{c})$ & - & \\
\hline$A d h-1 \mathrm{~A}$ a & Est-5B e & $-0.014^{*}$ & - & - & - & $-0.107 \mathrm{~ns}$ \\
\hline$A d h-1 \mathrm{~A}$ a & $M d h-2 \mathrm{~b}$ & $0.020^{* * *}(\mathrm{c})$ & - & - & - & $0 \cdot 149+(\mathrm{c})$ \\
\hline$M d h-2 \mathrm{~b}$ & Est-5B e & $-0 \cdot 080^{* * *}$ & - & - & $-0.032 \dagger$ & $-0.211^{* * *}(\mathrm{c})$ \\
\hline$A c p h-x$ a & Est-5B e & $-0.053^{* *}(\mathrm{c})$ & - & - & $-0.005 \mathrm{~ns}(\mathrm{c})$ & $-0.063 \mathrm{~ns}(\mathrm{c})$ \\
\hline Acph-x a & $M d h-2 \mathrm{~b}$ & $0.032^{*}$ & - & - & $0.000 \mathrm{~ns}(\mathrm{c})$ & $0.069 \mathrm{~ns}(\mathrm{c})$ \\
\hline
\end{tabular}

Significance: $*=p<0.05 ; * *=p<0.01 ; * * *=p<0.001$.

$\dagger=p<0 \cdot 10$; ns $=p>0 \cdot 10 ; p$ by chi square, with Yates correction, or by Fisher's exact test.

(c) = complete association: one gametic type is missing (Brown et al., 1980).

(a) = absolute association: only two gametic types are present (Brown et al., 1980).

were significantly assocated with temperature, water availability and geographic variables. (ix) Gametic phase disquilibria and intense multilocus organization were abundant.

The results obtained in $T$. $t$. dicoccoides in Turkey support the following hypotheses: (a) Wild emmer displays a unique archipelago-patterned ecological-genetic population structure. (b) Natural selection is a major factor in genetic differentiation of populations; and (c) The wild gene pool of emmer wheat can provide useful genetic resources for the improvement of the cultivated gene pools. These three hypotheses will be discussed sequentially.

\section{(a) The unique ecological-genetic population structure of wild emmer}

The population genetic structure of $T$. $t$. dicoccoides in Turkey is similar to that in Israel. It displays a unique ecological genetic population structure (Nevo et al., 1982; Nevo, 1983). While some northern populations in Israel are lush and comprise extensive stands, most populations are either semiisolated or isolated. This unique population structure is displayed by the fact that localized alleles were frequent ( 45 per cent in Israel and 54 per cent in Turkey), while rare alleles were few. Thus, the geographically subdivided population structure of wild emmer wheat is genetically reflected as an "archipelago" population genetic structure, where peaks of locally or sporadic alleles characterize the semi-isolated and isolated populations. These alleles are frequently correlated with environmental factors, displaying adaptive patterns. Furthermore, these are precisely the alleles that are critical in determining optimal sampling strategies (Marshall and Brown, 1975).

\section{(b) Natural selection as a genetic differentiator of wild emmer}

We have indicated in several previous communications the substantial importance of natural selection in adaptive genetic differentiation of wild emmer wheat at the macro- (Nevo et al., 1982) and 
Table 9 Estimates of multilocus genetic organization of $T$. $t$. dicoccoides in four populations in Turkey

\begin{tabular}{|c|c|c|c|c|c|c|}
\hline $\begin{array}{l}\text { Entire sample } \\
\text { In each population }\end{array}$ & 14 & 122 & $2 \cdot 475$ & $<3.354$ & $4 \cdot 225^{*}$ & $0 \cdot 707$ \\
\hline 1. Siverek ( $9 \mathrm{~km}$ west $)$ & 8 & 33 & $1 \cdot 849$ & $<2.931$ & $4 \cdot 161^{*}$ & $1 \cdot 251$ \\
\hline 2. Siverek ( $20 \mathrm{~km}$ east $)$ & 9 & 34 & 1.779 & $2 \cdot 614$ & $2 \cdot 286$ & $0 \cdot 286$ \\
\hline 3. Diyarbakir (22 km west) & 10 & 41 & $1 \cdot 548$ & $<2 \cdot 411$ & $2 \cdot 864^{*}$ & $0 \cdot 850$ \\
\hline
\end{tabular}

Significance: $*=p<0.05$.

$\uparrow$ Per pair of loci, after exclusion of heterozygotes and unscorable cases.

$\$ K=$ number of heterozygous loci in two randomly chosen gametes.

$\S X(2)=$ measure of multilocus structure.

microgeographical (Golenberg, 1986; Golenberg and Nevo, 1987; Nevo et al., 1988a, b) levels. We have drawn similar results from our present study, despite the low number of populations involved, due to the following reasons. (i) Geographic differentiation of allozymes in the four Turkish populations of wild emmer, at both $\mathrm{He}$ and in allele frequency of some single polymorphic systems is predictable, in part, by the climatic regime (water and temperature factors). (ii) The sharp genetic differentiation of allozymes over the $90 \mathrm{~km}$ transect, across the semi-isolated four populations, is far from random. By contrast, it displays significant gametic phase disequilibria at the two locus level. Furthermore, multilocus organization also appears substantive. The variance of the number of the expected heterozygous loci in two randomly chosen gametes provides a useful measure of allele association among different loci (Brown et al., 1980). When applied to the Turkish allozyme data of wild emmer, this test demonstrated the presence of widespread multilocus organization in the entire megapopulation, and in three of the four populations tested. On average, the variance in $K$ was 71 per cent higher than expected under random associations in the megapopulation. Within the four Turkish populations the range of multilocus association was: $29-125$ per cent (table 9). We have argued elsewhere (Brown et al., 1978) that such associations are the corollary of coadaptation. This, as argued later, strengthens the case for genetic conservation as a source of variation for future breeding.

Gametic phase disequilibria and genome organization between loci strongly suggest that genetic differentiation of wild emmer is caused by epistatic selection rather than by other factors such as random drift and inbreeding. It appears unlikely that random drift plays a major role in the adaptive differentiation discussed above. The very fact of ecological-genetic island structure, with different common alleles in different populations which are associated with climatic variation, negates the idea that drift is a major differentiating factor. Gene flow rates are indeed low in general in wild emmer, (mean of $1.25 \mathrm{~m}$ per generation at Yehudiyya, Israel; see Golenberg, 1986). However, over many generations, and due to historical flushcrash population processes, and active transfer of seeds by ants, mice and other animals, the semi-isolated populations must have exchanged genes.

Nevertheless, the degree of multilocus association varies drastically between the four populations most likely due to natural selection, since all other factors involved appear similar. Inbreeding and hitchhiking (Hedrick, 1982) still remain important agents leading to gametic phase disequilibria and genome organization. However, if these were the only, or even the major causes of the observed patterns, the variance among populations should have been low. The large variance between the populations tested in these parameters (tables 8 and 9) suggests that selection does play an important role in the genetic differentiation observed, over and above sheer inbreeding. Admittedly, we do not have as yet a method to appropriate the contribution of each of the potential random and nonrandom factors involved in genetic differentiation at the single and multilocus levels. We therefore suggest that until such a method becomes effective, the multiocus associations encountered and genetic differentiation in general are largely derived from natural selection. This could be directly tested both in greenhouse and field conditions by reciprocal transplantation and replacement series competition experiments for fitness parameters over several years. For a detailed discussion of multilocus structures in T.t. dicoccoides see Golenberg (1986). 
The utilization of $T$. $t$. dicoccoides in improving cultivated wheats

Utilization of wild genetic resources to improve cultivated plants has been discussed by Allard (1960) and reviewed by Feldman (1983);, among others. Wild emmer, as a donor of genes for resistance to stripe rust and high protein content, has been described by Grama et al., (1983, 1984). Many genes for resistance to $P$. recondita tritici have been identified in wild relatives of wheat and in rye (Secale cereale L.). Thirty-five genes for resistance to the pathogen have been identified in wheat (Browder, 1980). Some of these genes were transferred to wheat by interspecific or intergeneric crosses. Four genes (Lr9, Lr21, Lr22a and Lr28) were transferrred from other Triticum species; three (Lr19, Lr424, and Lr29) were transferred from Agropyron elongatum (Host) Beauv.; and two (Lr25 and Lr26) were transferred from rye (Moseman et al., 1985). The success obtained in transferring desirable genes from wild emmer into cultivated wheat indicates that this species represents an extremely valuable germplasm pool that must be widely used in wheat amelioration. The widespread potential genetic resources of wild emmer wheat, including various disease resistances, protein content, and resistance to various ecological stresses and elite agronomic traits have been partly reviewed by Nevo $(1983,1987)$.

\section{CONCLUSIONS AND PROSPECTS}

The wild gene pool of emmer wheat, $T$. $t$. dicoccoides, in Turkey, the recognized progenitor of cultivated wheats, was studied here both theoretically and practically. Theoretically, in an attempt to evaluate the evolutionary forces causing genetic differentiation of wild emmer wheat. Practically, as a potential and actual donor of desirable genes for the improvement of cultivated wheat. The Near East Fertile Crescent in general, is the centre of origin and diversity of wild emmer. In this area, during long-lasting evolutionary history, wild emmer developed wide adaptive diversity against multiple and variable pathogens, pests, and diverse ecological stresses. Since genetic variation is transferable from the wild to the cultivated gene pool, genetic diversity of wild emmer is optimal for future wheat improvement. The rich genetic diversity of wild emmer for multiple disease resistances, agronomic traits of economic significance, and environmental adaptations, is geographically structured, and is predictable by ecology and allozyme markers (reviewed in Nevo 1983, 1987).
Consequently, conservation and utilization programmes should maximize sampling strategies by following the ecological-genetic factors and allozyme markers as effectively predictive guidelines. Future intensive studies of wild emmer, primarily at the molecular level, could substantially contribute to wheat improvement and thus stabilize world food production.

Acknowledgements We thank D. Zohary for field assistance and E. M. Golenberg and T. Krugman for laboratory assistance This research was supported by grants from the Wolfson Foundation; The Israel Discount Bank Chair of Evolutionary Biology; the "Ancell-Teicher Research Foundation for Genetics and Molecular Evolution", established by Florence and Theodore Baumritter of New York, and by the Humana Inc., Kentucky.

\section{REFERENCES}

ALla RD, R. W. 1960. Principles of Plant Breeding. John Wiley \& Sons, Inc. New York.

ATLAS OF TURKEY 1961. Tanoglu, A., Erinc, S. and Tumertekin, E. (eds), Istanbul, Milli Egitim, Basinevi.

BROWDER, L. E. 1980. A compendium of information about named genes for low reaction to Puccinia recondita in wheat. Crop. Sci., 20, 775-779.

BROWN, A. H. D., FELdMAN, M. W. AND NEVO, E., 1980. Multilocus structures of natural populations of Hordeum spontaneum. Genetics, 96, 523-536.

BROWN, A. H. D., NEVO, E., ZOHARY, D. AND DAGAN, O. 1978 Genetic variation in natural populations of wild barley Hordeum spontaneum, Genetics, 49, 97-108.

FELdMAN, M. 1976. Wheats. In Simmonds, N. W. (ed.), Evolution of Crop Plants, Longman Ltd., London, pp. 120-128.

FELDMAN, M. 1983. Gene transfer from wild species into cultivated plants. Genetika, 15, 145-161

FELDMAN, M. AND SEARS, E. R. 1981. The wild gene resources of wheat. Sci. Amer. 244, 102-112.

GolenberG, E. M. 1986. Multilocus Structures in Plant Populations: Population and Genetic Dynamics of Triticum dicoccoides. Ph.D. Thesis, State University of New York at Stony Brook.

GOLENBERG, E. M. AND NEVO, E. 1987. Multilocus differentiation and population structure in a selfer, wild emmer wheat. Triticum dicoccoides. Heredity, 58, 951-956.

GRAMA, A., GERECHTER-AMITAI, Z. K. AND BLUM, A. 1983. Wild emmer as donor of genes for resistance to stripe rust and for high protein content. In Sakamoto, S. (ed.) Proc. $6 t h$ Intl. Wheat Genet. Symp., Kyoto, Japan, pp. 178-192.

GRAMA, A., GERECHTER.AMITAI, Z. K., BLUM, A. AND RUBENTHALER, G. L. 1984. Breeding bread wheat cultivars for high protein contents by transfer of protein genes from Triticum dicoccoides. In Cereal Grain Protein Improvement, Proc. Intl. Atomic Energy Ag., Vienna, pp. 145-153.

HARLAN, J. R. AND ZOHARY, D. 1966. Distribution of wild wheat and barley. Science, 153, 1074-1080.

HEDRICK, P. W. 1982. Genetic hitchhiking: A new factor in evolution? Bioscience, 32, 845-853.

kimber, G. AND feldman, M. 1987. Wild Wheats. An Introduction. Special Report 353 College of Agriculture, Univ. Missouri Columbia, USA. 
MARSHALL, D. R. AND BROWN, A. H. D. 1975. Optimum sampling strategies in genetic conservation. In Frankel, O. H. and Hawles, J. G. (eds) Crop Genetic Resources for Today and Tomorrow, Cambridge University Press, Cambridge, pp. 53-70.

MOSEMAN, J. G., NEVO, E., GERECHTER-AMITAI, Z. K., ELMORSHIDY, M. A. AND ZOHARY, D. 1985. Resistance of Triticum dicoccoides collected in Israel to infection with Puccinia recondita tritici. Crop. Sci., 25, 262-265.

NEI, M. 1972. Genetic distance between populations. Am. Nat., 106, 283-292.

NEJ, M. 1973. Analysis of gene diversity in subdivided populations. Proc. Nat. Acad. Sci, USA, 70, 3321-3323.

NEI, M. 1975. Molecular Population Genetics and Evolution. Elsevier/North Holland Publ. Co., Amsterdam.

NEVO, E. 1983. Genetic resources of wild wheat: Structure, evolution and application in breeding. In Sakamoto, S. (ed.) Proceedings of the 6th International Wheat Genetics Symposium, Kyoto University, Kyoto, Japan, pp. 421-431.

NEVO, E. 1987. Plant Genetic Resources: Prediction by Isozyme Markers and Ecology. In Rattazzi, M. C., Scandalios, J. G. and Whitt, G. S. (eds) Isozymes: Current Topics in Biological and Medical Research, vol. 16, Agriculture, Physiology, and Medicine, pp. 247-267.

NEVo, E., BEILES, A. AND BEN-SHLOMO, R. 1984. The evolutionary significance of genetic diversity: Ecological, demographic and life history correlates. In Mani, G. S. (ed.) Evolutionary Dynamics of Genetic Diversity, Lect. Notes Biomath., 53, 13-213.
NEVO, E., BEILES, A. AND KRUGMAN, T. $1988 a$. Natural selection of allozyme polymorphisms: A microgeographical differentiation by edaphic, topographical and temporal factors in wild emmer wheat (Triticum dicoccoides). (submitted).

NEVO, E., BEILES, A. AND KRUGMAN, T. 1988b. Natural selection of allozyme polymorphisms: A microgeographic climatic differentiation in wild emmer wheat (Triticum dicoccoides). Theor. Appl. Genet. (in press).

V.VO, E., GOLENBERG, E. M., BEILES, A., BROWN, A. H. D. AND ZOHARY, D. 1982. Genetic diversity and environmental associations of wild wheat, Triticum dicoccoides in Israel. Theor. Appl. Genet., 62, 241-254.

NEVO, E., ZOHARY, D., BEILES, A., KAPLAN, D. AND STORCH, N. 1986. Genetic diversity and environmental associations of wild barley, Hordeum spontaneum in Turkey, Genetica, $68,203-213$.

PLUCKNETT, D. L., SMITH, N. J. H., WILLIAMS, J. T. AND ANISHETTY, N. M. 1983. Crop germplasm conservation and developing countries. Science, 220, 163-169.

SAS. 1985. User's Guide, 5th edition. SAS Institute, Cary N.C. SPSS-x. 1966. User's Guide, 2nd edition. McGraw Hill, New York.

WRIGHT, S. 1965. The interpretation of population structure by F-statistics with special regard to systems of mating. Evolution, 19, 395-420.

ZOHARY, D., 1970. Centers of diversity and centers of origin. In Frankel O. H. and Bennett, E. (eds) Genetic Resources in Plants-Their Exploration and Conservation, Blackwell Sci. Pubs. Oxford. 